\title{
SCIENCE
}

Friday, February 16, 1917

CONTENTS

The American Association for the Advancement of Science:-

The Outlook for Agricultural Science: Promessor Eugene Datentrort ............ 149

Scientific Events:-

Sigma $X i$ in Duluth, Minn.: Dr. EUGENE VAN CleEr. The Hancock Mineral Collection: Profrssor JoHN E. Wolpr. The American Academy of Public Health .... 160

Scientific Notes and News ............. 162

University and Educational News ......... 164

Discussion and Correspondence:-

The Slides of the Panama Canal: Dr. BenJ.

L. Miller ...................... 164

Scientific Books:-

Lahee's Field Geology: Profressor HerdMaN F. CleLAND. Shäfer on the Endocrine Organs: DR. P. G. StiLes ............ 166

Race Hygiene in Norway: Chancellor David Starar Jordan ................... 167

A Census of the Periodical Literature of Chemistry published in the United States: MARION E. SPArKs and Promessor W. A. Noyes ... 168

The American Society of Naturalists: Profiessor Braduey M. Datis ............ 171

MSS. Intended for publication and books, etc., intended for review should be sent to Professor J. McKeen Cattell, Garrisonon-Hudson, N. Y.
THE OUTLOOK FOR AGRICULTURAL SCIENCE 1

WIтноUт wasting time in discussing the question whether there is such a thing as agricultural science, I desire to proceed at once to a brief review of the conditions both favorable and unfavorable to the progress of those scientific activities necessary to the improvement of American agriculture and the welfare of country people uph whom we all depend for our food supply, for the proper employment and treatment of our lands, and for certain human qualities best propagated and preserved in the life of the open country.

\section{THE PLAN}

No thinking man can fail to be deeply impressed with the magnitude and the far. reaching consequences of what might be called the American program for agricultural advancement.

This program took definite form in 1862 in the establishment of a national Department of Agriculture, and in the passage of the Land Grant Act, whereby a college of agriculture was established in every state of the union. It was characterized and vitalized a quarter of a century later by subsequent acts providing for an experiment station in connection with every agricultural college; and mightily advanced by state appropriations, in some instances multiplying many times the federal subsidy. So generous indeed were these appropriations that the $\$ 30,000$ of federal funds

1 Address of the vice-president and chairman of Section M, Agriculture, American Association for the Advancement of Science, New York, December 27, 1916. 
have been supplemented until the total revenues of certain institutions for agricultural research amount to no less than $\$ 200,000$ annually.

This combined federal and state program aims directly at an adequate and a permanent food-supply, and with equal directness it proposes to retain upon the land, if possible, a fair share of the intelligence, the learning, and the culture of the American people. This latter purpose may be called Utopian, but a little reflection will convince even the most skeptical that in no other way can our lands be properly handled, for farming is after all and in the last analysis an indivindual affair.

The incidental effect upon citizenship of such a systematic effort, especially in a democracy, is an interesting sociological and economic question, but it is quite aside from the present purpose, which is to analyze the agencies that have been awakened in the name of agricultural science and to distinguish as clearly as possible between those that are really helpful and others that by accident or otherwise have become attached like barnacles to the ship and whose load is even less serious than their resistance.

The sudden establishment of a national system of fifty institutions under combined federal and state support, and the engaging upon this extensive scale in both education and research in a hitherto neglected, if not despised, field was certain to be followed by results both desirable and undesirable. The combination is still further complicated by the fact that the new field has suddenly become popular, drawing into its vortex amounts of money never before equaled, and engaging the attention of all sorts and conditions of men, some seeking opportunity for real service, others attracted by the loaves and fishes, even by the crumbs.

It was as inevitable that certain results should follow the agencies here invoked as that other effects should follow causes.

For example, it is impossible to launch so pretentious a program without a vast amount of good resulting, and in this respect the most sanguine enthusiasts have not been disappointed. It is impossible to accomplish a public service of this character and magnitude without developing a body of earnest, capable and devoted scientists who work, not for reward, but for the good that they can do, and it is my desire here and now to pay tribute of respect to the hundreds, yes thousands of men and women who labor both day and night, who expose and often destroy their health in carrying forward this great work. They shall have their reward.

But it is also impossible to suddenly engage upon an extensive scale in a new and undeveloped field without drawing into the service both inadequately trained and mediocre men. It is impossible that a field should be popular without attracting the sensationally minded, and it is equally unlikely that so large an amount of public money could be expended without the creation of a vast and complicated administrative machinery.

It is for us who have been in this work almost from its beginning and who have seen with our own eyes both the wheat and the tares developing side by side to critically and somewhat sharply distinguish between the two. Not only should we do this among ourselves, but, difficult and unpleasant as the service is, we owe it to the public, we owe it to our institutions, and we owe it to ourselves to frankly state the conditions as they are, with a view to the correction of certain evils that have crept in and which, if not exterminated, will destroy not only the best work in agricultural science, but even the institutions that were founded and are operated for its advancement. 
THE FIELD

It can not be too thoroughly and universally understood and remembered that for the purpose of research, teaching and demonstration, agriculture means farming. Agriculture is so broad a term; it touches so many sciences and at so many points; its problems are so varied and the questions involved in their solution are so fascinating that the temptation to wander far afield is often well nigh irresistible.

However, the funds appropriated, whether public or private, were set aside for the express purpose of improving the quantity, quality, reliability and permanency of our food supply and for the welfare of those who work the land and who, experience shows, rapidly descend to the level of peasantry under conditions which they are unable to control without the assistance of science, the benefits of education, and the support of the public conscience.

Wherefore, we are to distinguish sharply between those lines of investigation that bear upon the business of farming and those collateral lines which, though they may arise out of the materials of agriculture, have yet little or no significance in the field of food production.

In saying this the writer is not to be understood as restricting the field to socalled practical lines. Far from it. For this purpose at least there is no distinction between what is practical and what is scientific. But let the scientist be not deceived by the materials with which he works. It is not the materials that determine whether a piece of work is truly agricultural; it is the outlook, the purpose, the application that is to be made, these are the tests, not as to the excellence of the work or its general significance, but as to its legitimacy, especially in the experiment stations.

Wherefore, these funds are not available for ordinary scientific research, however valuable, even though the materials involved be drawn from the farm. They are not available for the amusement or the personal enjoyment of the investigator; neither are they to be devoted to paying the expenses of aviation excursions into the rarefied and upper atmosphere of speculation even in so worthy a field as the socalled pure sciences.

The temptation to wander afield is not only due to the fascination of outlying pastures, but it is strengthened by the actual and frequent necessity of spending much time and energy in clearing up an abstract point which science in its imperfect state has not yet touched. But these excursions into outlying territories after truth necessary for purposes of further research are to be regarded as essential rather than logical; as a means to an end and never a purpose. At no point does the research man in agriculture need to step permanently aside for facts which science has not yet supplied, but which he must obtain before going ahead with his proper work.

\section{MEN}

Fortunately for some reasons, unfortunately for others, the time has come when agriculture is popular. Among the fortunate features of so happy a condition of affairs is the fact that we now command in this field the respect and the service of the highest grade of men with the best obtainable training. And if some are yet tempted to enter this form of service in the hope of premature, if not undue publicity, we have the satisfaction of believing that their numbers are growing relatively smaller.

Indeed, as matters stand to-day it would be difficult to find in any other branch of human activity a more self-sacrificing and public-spirited class of men than are those of our agricultural colleges and experiment stations. They have had some trouble, it is 
true, in obtaining in all cases suitable training, but their spirit and energy are certainly laudable, even calling often for restraint in the interest of health and the higher service.

A heavy weight of responsibility rests upon the young man now preparing for a career in agricultural research. It is not enough that he have some special knowledge and skill in a narrow field such as soil analysis, genetics or vegetable pathology. He must have scholarship, breadth of knowledge and vision enough to know the relation of his specialty to other branches of science, and the bearing of it all upon the business and the practise of food production, that is, farming.

For the purposes of the investigator a real knowledge of and sympathy with the actual operation of the farm and the problems of the farmer is not only desirable, but essential. Farming is a productive, not a speculative industry, and the problems of agriculture are those of production and distribution, not those of special opportunity.

Moreover, farming is a private business upon which the welfare of families depends -not a few scattered people, but a full third at least of all the population and constituting entire communities. This fraction of the race must not be disregarded or the earth will avenge herself not only upon the unsuccessful farmer, but upon the people as a whole, whose heritage, after all, the land is.

The agricultural scientist, therefore, must not make mistakes, or he will lead a whole people to disaster. Our philosophies may be wrong; they can be readjusted. Our conceptions of the solar system may be incomplete or wholly erroneous ; but everyday life will go on about the same. However, if we entertain wrong conceptions about the serious business of food produc- tion, the consequences are swift and merciless.

If we get too little out of the earth, population is unduly restricted or unutterably miserable; and if we win our sustenance by methods destructive rather than permanent, then our successors, if not we ourselves, will pay the penalty of our error or of our piracy. Science is our only reliance, but the agricultural engineer must make no mistakes. He must be no blind leader of the blind. Therefore he must know the business of farming.

Now this is easier said than realized. The college student has lived all his life in school. Learning has been his occupation. Moreover, we shall tell him that if he expects to be really valuable, he must not stop with the bachelor's degree, but he must do so much in addition and do it so well that he will inevitably and in good time achieve the doctorate.

How then can this young man know by experience the business of farming? $\mathrm{He}$ can not know it as the farmer knows it after fifty years of earning a living and of clothing and educating the family he has raised. This prospective scientist will work for a salary, which means an assured living while he studies and attempts to solve the problems of those who live by production.

The problem for the young scientist is not easy, and that is the reason for discussing it at length. It takes twelve years of child life to finish the high school and prepare for college. The student is twenty to twenty-two at graduation. Three years more for a doctorate puts him at twentythree to twenty-five. Besides, there is marriage to be considered, for farming is a married man's job, and bachelors as a class will never solve its problems. When and how is this man to get experience in actual farming?

Experience in supporting a family on 
the farm he can not have unless he owns a farm and becomes a real farmer, in which case he is out of our reckoning, for observation shows that such men are not likely to return to the public service except after failure, when they are not desirable.

It is impracticable, in the opinion of the writer, to require farm experience as a condition either of admission to college or of graduation, largely because of the difficulty of ascertaining and certifying what constitutes satisfactory experience ; but it is possible to require actual farm experience as a prerequisite to certain elective courses of instruction, leaving the teacher to determine sufficiently for his purpose a question that has no complete solution.

It has long been the custom of the writer to advise every student in agriculture who has not lived a full year in actual work upon a real farm to drop out in the middle of the sophomore year and get it. This particular time is recommended as affording enough scholarship to enable him to look at the matter from the student's point of view, as being less valuable than later years, involving less embarrassment to the student, and as calculated to greatly enrich the later years of study. This is recommended for all students of agriculture, whether headed for farming or for a scientific career; and without at least this much of actual touch with real rather than paper farming, the future usefulness of the experiment station man is far from assured.

Much space is devoted to this subject because it looms large in public affairs just now. In conversation the other day with the most prominent Hindoo philosopher now living, and whose son graduated in the agricultural college of the instituition I represent, this extensive landholder complained of the lack of practical knowledge or even of appreciation of the conditions actually and necessarily confronting the Indian farmer on the part of men in the public service and presumably qualified to advise and assist the people with an improved solution of their very difficult problem. They know certain scientific facts as abstractions, but to be useful somebody must make the application to practise and this application should be made by educated men.

No conception needs to be more firmly impressed upon the young agricultural scientist at this juncture than the fact that agricultural research is not a game for the amusement of the players, but a real search after truth to be employed in the solution of one of the profoundest of human problems, whether regarded from the standpoint of the individual farmer on his farm, or of public service to a people at large-consumer and producer alike.

\section{VERIFICATION}

One encouraging feature of the problem is the fact that the findings of scientists are to have abundant and able verification or correction in the field.

The thousands of farmers who are reading the bulletins of the experiment stations, the hundreds of agricultural students going from our fifty colleges and a growing number of schools back to the farm are all putting to the test, and intelligently too, under a vast variety of conditions, the tentative findings of the specialist. Here lie both safety and inspiration, but the obligation of the scientist to be always and everlastingly right is not lessened.

The business of verification is still further extended and intensified by the system of local improvement associations or farm bureaus, each employing an adviser who, when competent, as he commonly is and as he always ought to be, forms a nucleus for really effective service in actually putting to the working test whatever is new or promising in the business of farming. Fortunately the relations be- 
tween the system of advisers and the experiment stations and the colleges of agriculture are very intimate. It looks as though in them the machinery at least for improved and reliable food production is fairly well assured.

\section{POLICE WORK}

However, there are always perils in the most promising journeys into unexplored territory or in sailings upon uncharted waters.

The experiment stations are new, and fortunately whatever else may be said they have now the confidence of the farmers, who have come generally to feel that a new force is in affairs and that a new help to farming has appeared in that indefinite thing we call service.

Now there is always a temptation to put sacred things to ungodly uses, and the experiment stations have not escaped the operation of the general law. Science has shown that a certain disease or pest can be controlled, and it has pointed out the method of doing it. What more natural than that the public should take the stations at their word, and say "Very well, here is an appropriation; go ahead, make your serums and your rules to put the thing into practise ; hale citizens into court ; fine or imprison them if necessary, but make it work"?

Now this is hasty logic and bad practise. The experiment stations are organized for research, not for administration. Again, it is unseemly that a creature of the public like a scientific institution should appear against citizens in the courts and fine or commit them to jail. Besides, the experiment stations have no militia with which to suppress resistance, which in such cases as foot and mouth disease is as ever present as time and as explosive as a volcano.

Besides, the object of the scientist is research, and how shall the experiment sta- tion carry on further investigation after new truth if it must stop short and enforce the accumulating mass of revised practise. It will soon be so cluttered up under such a policy that new work is impossible and most of its funds and laboratory space will be used for the purpose of "regulatory work," when further progress is practically impossible, a condition that has already overtaken certain of the experiment stations and is all too rapidly threatening others.

The only safety either to the research worker, the station or the public is for the investigator to verify his discoveries, point out the method of their practical use, and go on after other truths, leaving the public to make such use of the new knowledge as it deems wise and relying upon the usual police power of the state for its enforcement, if enforcement is necessary. In no other way can research be protected; in no other way can the stations discharge the public service for which they were organized; and in no other way can the confidence of the public be indefinitely enjoyed.

\section{THE CULT OF ADMINISTRATION}

The rate and the intensity with which administration under one pretext or another is coming to dominate research in this country, especially along agricultural lines, is little short of appalling to any candid observer who takes stock of the situation and who has the courage of his convictions.

Many if not most investigators in agriculture are now required to begin a piece of research work by drafting a formal project in which the materials and methods are definitely described, the cost specified, and the expected results foretold. The method is akin to a new turn of a kaleidoscope, or the setting of a new combination on a complicated machine which, after all the new adjustments of pins, screws and levers have been carefully made, is expected to go 
ahead of itself and grind out what might be called inevitable results.

This process is intended as a standardizing procedure, and if results are not soon forthcoming, reports of progress are due from time to time as a kind of perpetual guarantee, on the installment plan, that the thing was worth doing and that the specialist is still "on the job" and not loafing or skylarking off into the wilderness fishing and hunting as scientists are prone to do!

Before anything can actually be done, however, this project, in many branches of the public service at least, must be submitted to administrative review, in order to learn whether the work, however valuable, can be legally performed. I confess to extreme difficulty in treating this portion of my theme with such moderation of language and statement as are appropriate to the dignity of the occasion, and when I fail let the exigency of a just cause be my excuse.

A mass of hirelings called clerks now pounce upon the project, one after the other, each intent, not upon helping forward a valuable piece of public service, but upon seeing if perchance. he can not find some statute law, court decision or office ruling that makes the thing illegal and therefore impossible.

In this enterprise the hireling will take no chances. He is not there to promote the public service, but to regulate it, and to see that everything is done decently and in order. If service is prevented altogether, that is no business of his. Everybody must justify his job, and the more things get stopped the more importance is attached to restrictive methods. If everything goes through, many clerkships would be abolished.

Nor should this hireling be condemned when he reports adversely upon a perfectly good thing because it perchance runs counter to the ruling of a public official, even though made many years before in another department under conditions quite dissimilar and by a man of questionable ability, long since dead and practically, if not entirely, forgotten. This clerk was put there to find objections, and it is little wonder that he discovers among the accumulation of laws, decisions and rulings reason enough for stopping many of the things that come his way. After this arbitrary fashion is progress made unduly difficult.

When this project returns to the specialist, battered and beaten, he sets about to reconstruct the plan, using so much of the original as may have passed the various censors, introducing new material to fill the gaps, and sends it out again to run the gauntlet. After repeated journeys and final approval, the real worker at last sets about the task of endeavoring to accomplish something.

But the troubles of the investigator have only begun when the project is finally approved. He needs some new and special equipment and makes out a requisition in quintuplicate and three colors, praying $\mathrm{His}$ Majesty the Purchasing Agent to provide the materials for his work-of course out of funds already set aside for his department.

At the best, he must satisfy the business office that no other equipment will answer his purpose and that no other can be bought so cheaply. At the worst he may find that his specifications have partially or entirely been ignored and material ordered which he can not use, and often, through unfamiliarity of "the office" with the tricks of the trade, he is actually mulcted in the purchase.

But this poor project is not through with its troubles. The would-be investigator learns that the purchasing agent is not, after all, a free moral agent, but is himself an hireling. He learns that even the board of trustees, which was elected by the people to operate the university, are not free to use 
their judgment, but have certain overlords at the state capitol in the form of special commissions appointed by the governor, and represented mostly by clerks empowered by law to ride rough shod over all conditions.

$\mathrm{He}$ finds-this scientist and would-be public servant-that his requisition for equipment must first of all be sent to the board of prison industries in order that anything made in the penitentiaries of the state may be substituted for his specifications, and that too regardless of price, over which neither he, nor the purchasing agent, nor even the board of trustees, has the slightest authority or even influence.

And still his troubles are not finished. Unkindest cut of all, he may not even select the assistant upon whose skill and faithfulness the outcome will largely depend. This assistant, secretary, clerk, or stenographer, whatever he may happen to be, will be selected upon examination by an outside body miles away, consisting of men appointed under half the salary of the investigator-and glad to get it-men who were never in his or any other man's laboratory, yet who presume to say and do say who shall be employed and who shall not be employed.

Not only are assistants appointed from without, but that form of administration which consists of reviewing projects or other supervision is performed by men appointed after the same manner. In this way it often happens that a mediocre neophyte "supervises" the investigations of his own teacher who was indiscreet enough and tender-hearted enough a few years ago to give him a passing mark against his own better judgment.

As a final blow to his personal pride and enthusiasm, this investigator learns that he will be unable to report his results in the form he most desires because the state printer or the prison shop is unwilling, or what is more likely unable, to do the work as it should be done, neither will they "release" the job that it may be done as it would appear in ordinary work from institutions not overriden by administration.

He even learns that the very building in which he works, and whose insufferable ugliness and unnecessary cost have amazed him, was planned by a state architect, overruling the supervising architect of the university; and that the building across the way, of another form of ugliness and inefficiency, was executed by another state architect of a succeeding "administration," again overruling the institution, its school of architecture, and its board of trustees, even though the autocrat knew so little of his business as to be unable to draw plans and specifications upon which builders would file a bid. So do administration and law prevail over knowledge, needs and reason, for this is an actual experience.

This investigator, discouraged, disgusted, if not disheartened at least with the keen edge of inquiry long since dulled, says in his heart: "I will arise and hie me to another institution where the needs of the work are held supreme over methods of procedure and exploitation of positions and funds."

Vain hope! He may find temporary relief at certain points, but it is only temporary, for the conditions described, while not all as yet operative in any one place, are every one in operation to-day somewhere among institutions given to agricultural research and are rapidly extending to all the publicly supported institutions.

As a last example of the absurd extent to which administration has been pushed, this investigator-qualified by long years of training and experience-will find, in not one but many institutions, that should his duties lead him outside the confines of his 
state, he may not go at public expense without the permission of the governor.

His own knowledge of the needs, his training, judgment and loyalty count for nothing. His desire to economize funds, dearer to him than to anybody else, funds that have been exploited time and again by officers over whom neither, he nor the board of trustees have the slightest control-this desire is no guarantee of his judgment. The opinion of the head of the department does not count. The recommendation of the president is void of meaning. The action of the board of trustees is impotent. The question must go to the governor of the state - this mighty question as to whether Dr. Blank, scientist at $\$ 4,000$ per year, may step across the border to consult his brother scientist and have his expense bill of $\$ 7.93$ paid from funds appropriated by the legislature and set aside by the trustees for this very purpose. Ye gods, where are we drifting!!

If this burden were from within the institution the case would be different, because it could the more easily be removed. But it is inflicted from without under the pretext of auditing, or of efficiency, and with certain federal funds we have reached a stage of affairs such that the specialist may work only in "cooperation" with offices a thousand, perhaps two thousand, miles away and represented by men who know little of the local conditions involved-a cooperation at best that is purely administrative, mostly restrictive, wholly artificial, and defensible only as a means of administration. So has administration become not only supervision, but actual cooperation, under which the last opportunity for personal initiative and the best service is taken away.

All this is done in the name of one or the other of two agencies-the administration of public funds, or the demands of effciency.

Officers connected with federal and state administration seem to be unable to distinguish between the business of auditing and that of supervision. They reason that if they are in any way to certify funds they must also approve the work. In this way has ordinary auditing developed within twenty-five years into what was at first inspection of work and at last a kind of "cooperation" in which the one to be held responsible for results is under the dominance of authority entirely outside the institution which he serves. In this way an outside individual, even a minor officer, is able to overrule a university and its entire administrative machinery.

Efficiency is more insidious, for it works under the guise of service and proves by figures that scientists, teachers and others in the public service must be standardized in order to be made efficient, and before this car of Juggernaut, training, loyalty, counsel, experience, even deliberative acts of boards of trustees of successful and highminded citizens serving without salary do not count as against a small group of selfselected and politically appointed individuals shut up in an office miles away with neither special training, knowledge of the situation nor other qualification to enter our laboratories but the blind authority of law working in the dark and largely through individuals who would never, except by the accidental working of law, be connected in any way with our work. So are useless and pestiferous positions multiplied and made parasitic upon a most excellent service.

\section{LITTLE ADMINISTRATION NECESSARY}

Administration can not vitalize research. Its whole effect is restrictive and hence should be reduced to a minimum. That it 
is not necessary to good work is shown by the seventy-five years' experience at Rothamsted. That auditing accomplishes all that is necessary in addition to the public reports of responsible boards of trustees is shown by the experience of numerous institutions not yet under the blighting effects of too much administration. That administration is recognized as a deterrent to good work is shown by the struggles of the state universities everywhere, not only to free themselves from this outside dominance that is wasting funds, and crushing the life out of institutions and men, but they are also simplifying their own internal machinery to the end that nothing should come between the worker and his work.

All progress in science is the result of individual interest, initiative, invention and energy, all of which must be resident in the worker. The driving force that brings results is internal, not external, to the explorer after new truth. It beckons from ahead and does not prod from behind. It is akin to that attraction which drew explorers time after time to the pole, and not akin to the whip that sends the slave to the galley or the cotton field.

Administration does no work. It is a harness put upon activity. Its purpose is not to actuate, but to restrain and forbid, as witness the multitude of laws, boards, commissions, decisions and rulings that have grown up-all restrictive. "Thou shalt not" is the burden of most administrative legislation and office rulings.

The effect is delay, added expense, discouragement of men, and unsatisfactory service at every step, for after engaging the best available men, administration proceeds to tie their hands and to exploit their funds.

\section{EFFECTS OF ADMINISTRATION ON MEN}

The effect of too much administration upon the scientific worker is at first one of disappointment, then of discouragement, and finally of disgust. Conditions as they are now developing not only constitute an unhealthy example for our young men in college, but they are deterring thoughtful men from entering the public service. Real men are unwilling to subject themselves to unnecessary restriction and petty annoyances, the obvious exploitation of funds and the artificial multiplication of administrative positions, with their overhead charges upon research and their power to bring reproach upon the best intentions and the most faithful service. There is danger to everybody when the crash comes, as it will come when the public begins to understand the foreign forces that have attached themselves to the serious business of research in agriculture.

But it is objected that without supervision much time and money are wasted; besides some men are lazy. Granted without argument! As to waste of time and money, some of both is inevitable. Many excursions were made northward before the pole was conquered. Perhaps some money, even lives, were wasted, but not the attempt as a whole. At the most no scheme could be invented that so inevitably leads to time service and fraud as the one now building up around our institutions where the public is made to feel that nobody is either honest or capable save the "inspector" and the appointed overlord who gets his commission by executive appointment and reports to nobody. What guarantee have we of his honesty?

Mod'ern efficiency standards are developed from the manufacture of shoes, clothes-pins, overalls, etc., and are expressed in motions per hour. These standards are not applicable to research. Money put into research is bread cast upon the waters. In the serious business of searching after new truth, no man knows in advance the road 
that shall be traveled before he may stand upon the heights. He may be held down, but he can not be pushed up. No power on earth is so impelling as his own initiative and determination to achieve.

Under what project did Darwin work? Did Faraday report regularly upon the progress of his mental wanderings after firm resting places? Could the searchers after the principle of radioactivity report progress from time to time? How shall we, even in the interest of efficiency, record the Sermon on the Mount or the Gettysburg address in terms of laboratory hours? Go to, we are dealing with strange gods at this point. Let us be forgiven and return to the worship of the true Deity which is ready to recognize the individual as the source of all real discovery and which is willing to accredit him with as much of honesty of purpose, and of faithfulness to the public as the political appointee, also an hireling. Above all let us not set up to rule over us machinery that is manned by those individuals who could not themselves do the work they attempt to supervise. And above all I protest against the present temper of the public mind which has been tampered with by professional exploiters until it is unwilling to trust its business in the hands of boards or other deliberative bodies even when composed of reputable citizens busy for the most part about their own affairs, but overrules their judgment by exalting individuals who have no occupation of their own but whose profession it is to multiply and to fill administrative - positions, that render no service but that hinder mightily the progress of the true scientist whose one occupation is research.

Here have come together the working scientist and the professional officeholder. They face in opposite directions. At present the office man has the upper hand. He assumes the rôle of critic and the public has accorded him all he asks. The time will come, however, and may it not be long delayed, when the scientist will again come into his own and the institution to which he belongs will recognize no overlord, except the auditor, who will be an auditor, not an autocrat in technical science.

\section{THE RANGE}

So thoroughly has chemistry taken the lead as a science fundamental to all improvement in agriculture that the terms are sometimes used synonymously. However, the outlook for the development of other sciences in their relation to agriculture is extremely suggestive. Physics, for example, has never consciously served farming. I know of but two graduate students in agriculture who have specialized in physics, and it was the experience of both that physicists were somewhat surprised to learn that their science could be of the slightest use in agriculture, whereas the facts are, it is of fundamental importance at many points.

Both botany and zoology possess undeveloped opportunities little dreamed of. They have in the past served agriculture mainly in the field of genetics or of animal and plant diseases. We are only beginning to study crop production from the standpoint of the physiology of the plant, its sensitive periods and the conditions essential to successful growth.

As a whole we have only scratched the surface of science in its relation to the practise of farming. The outlook is nothing short of a panorama to him who has an adequate vision of the future and the ability to work in any one of the great fields of science, distinguishing clearly between science per se and its application to the arts of man.

The writer is not pessimistic and is in no sense discouraged with the outlook. $\mathrm{He}$ is 
concerned only with matters as they stand. Some of the conditions of which we complain are accidental and deplored as much by the administrative officers who happen to be in charge as by the scientific workers in the laboratories. Others are the result of a more or less wholesale desire to exploit a situation which enjoys large appropriations of public funds. This is the element that must be sloughed off at all cost.

The public who is to be served and who pays the bills will ultimately clean the stables, if only the scientists and the institutions who have permanent reputations to defend and who outlive successive generations of appointed overseers will be true to their responsibilities and insist upon working conditions favorable to reasonable results.

No other branch of science is so richly endowed as is agriculture; no other promises such important results; no other has so large an army of men faithful to their duties; no other so enjoys the confidence of the public. The question is, shall agricultural science with all these advantages weighed against the disadvantages be stronger or weaker than other branches of study, and can the publicly supported institutions with superior revenues afford equal advantages for research as compared with independent institutions resting upon private funds?

\section{UNIVERSITY OF IILINOIS}

\section{E. Davenport}

\section{SCIENTIFIC EVENTS}

SIGMA XI IN DULUTH, MINN.

The "Quarter Century Record and History" of Sigma Xi appeared in 1913. It contained, among other valuable information, the names and addresses of all those elected to Sigma Xi up to December 31, 1911. Mr. Eugene Van Cleef conceived the idea of organizing the members residing in Duluth, believing that such an organization could prove more or less successful. As a result of a little correspondence and personal interviews "The Society of Sigma Xi of Duluth, Minn.," was consummated with 10 charter members in July, 1913.

Meetings are held bimonthly. A dinner is served after which an informal paper is presented by one of the members and discussed by all. The wives of the members and a lady friend of each of the unmarried members may be guests at any meeting. Their attendance has been almost as regular as that of the men.

Each paper has covered some phase of the work in which the respective members are engaged. The nature of these presentations may be gained from some of the following titles selected at random: Heredity and Environment; The Valuation of Public Utilities; Design and Construction of the Aerial Bridge at Duluth; Climate and Man; The Learning Process and Acquisition of Skill, etc.

At present the membership consists of $\mathbf{3}$ mechanical engineers, 1 civil engineer, 1 agriculturist, 1 geographer, 1 physician and 1 psychologist. With such a variety of interests represented each one is assured of receiving information worth while at each meeting. The discussions are thoroughly alive and stimulating.

That the meetings have been worth much to each one is attested by the fact that the attendance for the past four years has been almost perfect, no one being absent unless because of circumstances over which they have had no control.

This announcement is made to the readers of SoIEnCE, in the belief that others may care to adopt the idea in the locality in which they are now residing. There seems to be no reason for the cessation of interest in the welfare of Sigma $\mathrm{Xi}$ just because one is not engaged in academic work. The spirit of research should live after college days among all members of Sigma $\mathrm{Xi}$, regardless of the course in life which they may pursue. Details of the organization in Duluth, not cited above, will be gladly given to any who may apply to the undersigned. Eugene Van CleEF

State Normal Schoor, DULUTH, MinN. 